DOI: $10.2478 / \mathrm{v} 10025-010-0031-8$

\title{
The effect of hydrogel additives on the water retention curve of sandy soil from forest nursery in Julinek
}

\section{Piotr LECIEJEWSKI}

Warsaw University of Life Science, Faculty of Forestry, Department of Forestry Utilization, ul. Nowoursynowska 163,02-787Warszawa, Poland; e-mail: piotr.leciejewski@wl.sggw.pl

\begin{abstract}
Forest nurseries are mostly located in light and very light sandy soil sites. They are characterised by low water holding properties in the aeration zone, and their water resources depend mainly on precipitation. One of the possible ways to solve this problem is to use hydrogel additives to soils.

The objective of this study was to investigate the influence of polyacrylamide SuperAbsorbent Plus on water retention curve of a sandy soil from forest nursery in Julinek. Surface soil layer $(15 \mathrm{~cm}$ deep) was collected for experiments. It was mixed and divided into 5 parts. Each part, except control, was enriched with hydrogel additives in the amount of $0.5,2,4$, and $6 \mathrm{~g} \cdot \mathrm{dm}^{-3}$. Six samples were taken from each soil part with hydrogel treatment and from control soil (without hydrogel). Water retention was measured with the Soil Moisture Equipment Corporation (Santa Barbara, California, USA) - LAB 012 in Agrophysics Institute in Lublin.

Results of soil moisture at particular water potential values were shown as $\mathrm{pF}$ curves, and the analyses of soil retention properties were performed for particular $\mathrm{pF}$ ranges adopted after WALCZAK et al. (2002).

Soil treatment with hydrogel increased soil retention properties, mainly in the range of $\mathrm{pF}$ less then 2.0. The largest increase of retention capacity was found in the range of $\mathrm{pF} 0-2.2$. It means that hydrogel accumulates the gravitation water in the soil, which under natural conditions rapidly permeates the soil profile and becomes unavailable for plants.
\end{abstract}

Key words: hydrogel, PAM, polyacrylamide, sandy soil, soil conditioner, soil water retention

\section{INTRODUCTION}

Forest nurseries are mostly localised in habitats of light or very light soils. Such soils have poor abilities to retain water in the aeration zone. The success of seedling culture depends thus on water conditions i.e. on precipitation. Precipitation deficit is much more harmful in large than in small nurseries. The latter are surrounded by dense forest which minimizes soil drying by limiting wind velocity and insolation. Irrigation is determined by available water sources of appropriate quality and output which is often problematic. Difficulties in providing proper soil 
moisture in root zone may deepen in the future due to climatic changes i.e. increased air temperature and decreased precipitation. Climatic changes may cause problems with the access to water sources and with more intensive transipration and drying of the top soil layer.

One of the ways to solve these problems is to apply polymer hydrogels (super-absorbers) as soil additives. The capacity of hydrogels to absorb water would allow restricting the effects of its deficit through more efficient use of rainfalls and water from sprinkling irrigation.

\section{STUDY AIM}

The aim of this study was to test the effect of polymer hydrogel additive (Super Absorbent Plus) on the water retention curve of sandy soil from forest nursery in Julinek.

\section{MATERIAL AND METHODS}

Top soil layer (poor loamy sand) to the depth of $15 \mathrm{~cm}$ was taken for analyses from quarter no. 5 in forest nursery in Julinek. The soil was mixed and divided into 5 parts. Each part, except the control, was mixed with pre-defined hydrogel additive of $0.5,2,4$, and $6 \mathrm{~g}$ per $\mathrm{dm}^{3}$ of soil. Then, distilled water in small portions was added to each variant until it appeared on the soil surface when the soil was mixed. Six samples were taken from each soil part, including control, with metal cylinders of known weight and the same volume. Before measurements cylinders with soil samples were immersed in water for 24 hours. Measurements of water retention during drying were performed with the apparatus LAB 012 made by Soil Moisture Equipment Corporation (Santa Barbara, California, USA). Obtained records of moisture at particular variants of soil water potential $(\mathrm{pF}: 0,1,1.5,2,2.2,2.5,2.7$, $3,3.2,3.7$, and 4.2) were presented in a form of $\mathrm{pF}$ curves and the analysis of water retention properties of this soil was performed in particular $\mathrm{pF}$ ranges according to WALCZAK et al. (2002).

Soil conditioner Super Absorbent Plus ${ }^{\circledR}$ - a non-toxic polymer gel approved by the State Department of Hygiene (seal of approval PZH/HT-0675/2000) as safe for people and environment was used in the experiment. Super Absorbent Plus ${ }^{\circledR}$ is a highly cross-linked polymer produced from potassium polyacrylate. Hydrogel has a form of fine-grained white-cream coloured substance of the grain size less than $2 \mathrm{~mm}$ and a faint smell of organic acid, water content up to $15 \%$ and $\mathrm{pH}$ of 6.0-6.8. The main feature of the substance is its high hygroscopicity. According to information of the producer 1 gram of polymer may absorb $500 \mathrm{~g}$ of water (avail- 
able for plant root system in 95\%) forming hydroactive gel which after 7-10 years undergoes complete biodegradation in soil.

Analysis of the grain size structure of studied soil was made with the method of Cassagrande in Pruszyński's modification. Based on performed analyses the soil was estimated as light loamy sand containing $80 \%$ of the size fraction from 0.05 to $2 \mathrm{~mm}$ (Tab. 1).

Table 1. Grain size structure of soil from quarter no. 5 of forest nursery in Julinek

\begin{tabular}{c|c|c|c|c|c|c|c}
\hline \multicolumn{7}{c|}{ Granulometric composition $(\%, \varnothing$ in $\mathrm{mm})$} & \multirow{2}{*}{ Soil } \\
\hline $2.0-1.0$ & $1.0-0.5$ & $0.5-0.25$ & $0.25-0.1$ & $0.1-0.05$ & $0.05-0.002$ & $<0.002$ & \\
\hline 0 & 1 & 14 & 53 & 15 & 16 & 1 & light loamy sand \\
\hline
\end{tabular}

Soil $\mathrm{pH}$ was measured with the electrometric method, available components $\left(\mathrm{P}_{2} \mathrm{O}_{5}, \mathrm{~K}_{2} \mathrm{O}\right.$, and $\left.\mathrm{MgO}\right)$ - with the Egner-Riehma method, organic carbon $\left(\mathrm{C}_{\text {org }}\right)-$ with modified Tiurin's method, total nitrogen $\left(\mathrm{N}_{\mathrm{og}}\right)$ - after modified Kjeldahl procedure, $\mathrm{CaCO}_{3}$ - with the Scheibler's method (Tab. 2).

Table 2. Chemical composition of $0-20 \mathrm{~cm}$ soil layer from quarter no. 5 of forest nursery in Julinek

\begin{tabular}{|c|c|c|c|c|c|c|c|c|c|}
\hline \multirow{2}{*}{$\mathrm{pH}$} & \multirow{2}{*}{$\mathrm{CaCO}_{3}$} & \multirow{2}{*}{$\begin{array}{c}\mathrm{C}_{\mathrm{org}} \\
\%\end{array}$} & \multirow{2}{*}{$\begin{array}{c}\text { Humus content } \\
\%\end{array}$} & \multirow{2}{*}{$\begin{array}{l}\mathrm{N} \\
\%\end{array}$} & \multirow{2}{*}{$\mathrm{C} / \mathrm{N}$ ratio } & $\mathrm{P}_{2} \mathrm{O}_{5}$ & $\mathrm{~K}_{2} \mathrm{O}$ & $\mathrm{MgO}$ & $\mathrm{Al}$ \\
\hline & & & & & & \multicolumn{4}{|c|}{ mg per $100 \mathrm{~g}$ of soil } \\
\hline 5.1 & 0.000 & 1.246 & 2.148 & 0.122 & 10.2 & 6.8 & 2.2 & 7.0 & 0.36 \\
\hline
\end{tabular}

Bulk densities of soil with and without hydrogel additives were calculated from the ratio of mass of the soil dried at $105^{\circ} \mathrm{C}$ to its volume (Tab. 3).

Table 3. Bulk density of soil with various hydrogel additives $\left(0.5,2.0,4.0\right.$ and $6.0 \mathrm{~g}$ per $\mathrm{dm}^{3}$ of soil) and of control soil - without hydrogel

\begin{tabular}{c|c|c|c|c|c}
\hline Parameter & Control & $0.5 \mathrm{~g}$ & $2.0 \mathrm{~g}$ & $4.0 \mathrm{~g}$ & $6.0 \mathrm{~g}$ \\
\hline Bulk density, $\mathrm{g} \cdot \mathrm{cm}^{-3}$ & 1.67 & 1.62 & 1.56 & 1.41 & 1.29 \\
\hline
\end{tabular}

\section{RESULTS}

In this chapter the analysis of the water retention curves within soil water potential from $0.1 \mathrm{kPa}(\mathrm{pF} 0)$ to $1554 \mathrm{kPa}(\mathrm{pF} 4.2$ ) i.e. the relationship between soil suction pressure $(\mathrm{pF})$ and water content (moisture in $\% \mathrm{vol}$ ) for all experimental variants was performed.

The effect of various doses of hydrogel on water resources in soil was checked for particular ranges of water potential from $\mathrm{pF} 0$ to $\mathrm{pF} 4.2$ (Fig. 1). 


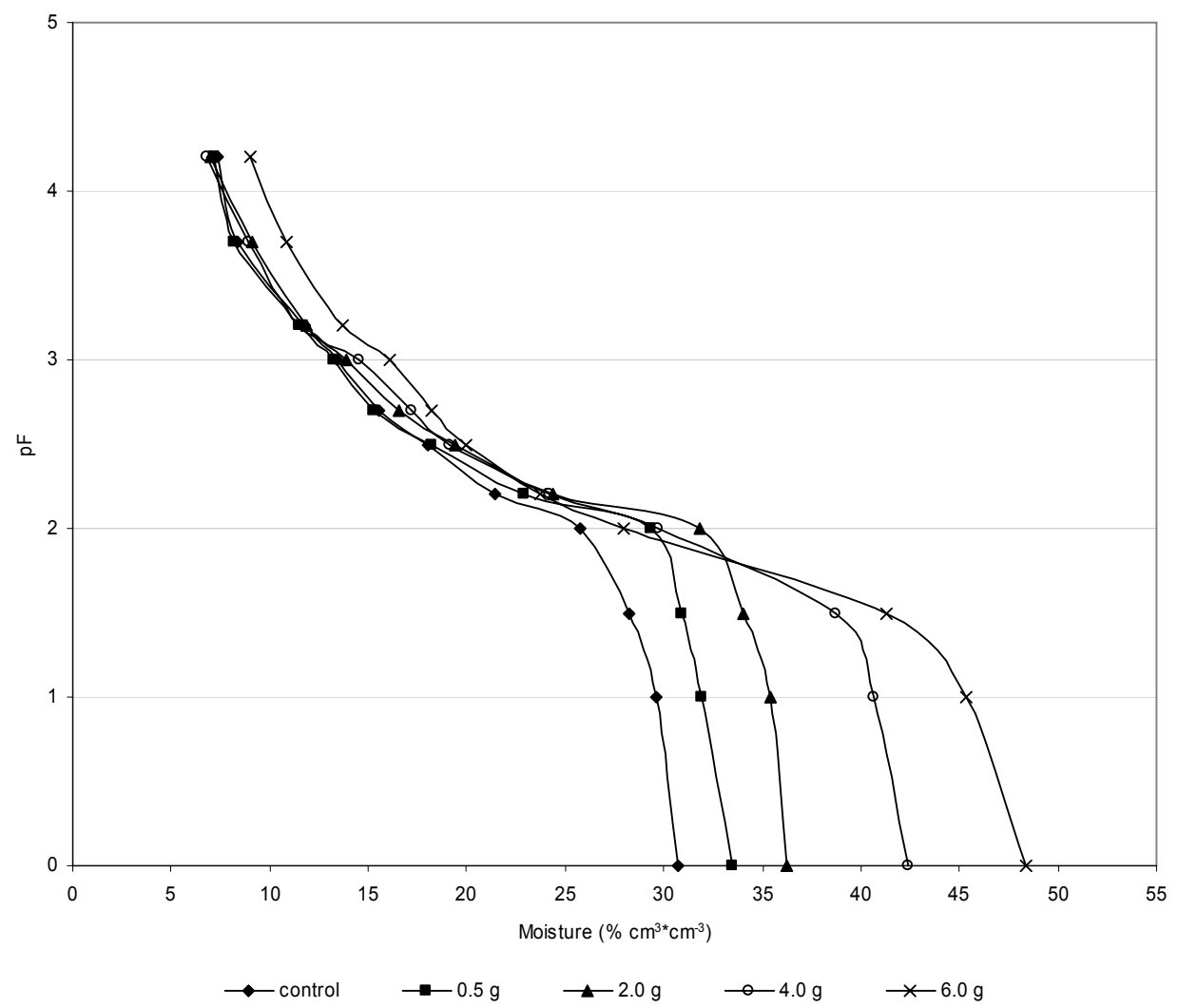

Fig. 1. The curves of water retention in soils enriched with various doses of hydrogel $(0.5,2.0,4.0$ and $6.0 \mathrm{~g}$ per $\mathrm{dm}^{3}$ of soil and in control soil - without hydrogel)

Retention in the point of permanent wilting, $\mathbf{p F}>\mathbf{4 , 2}$. The effect of superabsorber was ambiguous. At smaller doses of hydrogel $\left(0.5,2\right.$ and $\left.4 \mathrm{~g} \cdot \mathrm{dm}^{-3}\right)$ a decrease of soil retention capacity was observed as compared with the control. Enrichment of soil with $6 \mathrm{~g}$ of hydrogel per $\mathrm{dm}^{3}$ markedly increased retention capacity of soil in the point of permanent wilting.

Resources of hardly available water. Hydrogel increased soil water capacity in the range of $\mathrm{pF}$ from 3 to 4.2 . The largest increment in retention capacity (28\%) compared with the control was obtained in the variant with $4 \mathrm{~g} \cdot \mathrm{dm}^{-3}$. Hydrogel doses of 2 and $6 \mathrm{~g} \cdot \mathrm{dm}^{-3}$ increased water retention capacity in soil by $13 \%$ and $16 \%$, respectively. The variant with the smallest hydrogel additive did not affect the amount of water hardly available for plants.

Resources of easily available water. The largest increment of retention capacity at $\mathrm{pF} 2.2-3$ was noted for the addition of $2.0 \mathrm{~g} \cdot \mathrm{dm}^{-3}$ hydrogel (increase by $31 \%$ as compared with control). Superabsorber used in doses of 0.5 and $4 \mathrm{~g} \cdot \mathrm{dm}^{-3}$ 
increased water retention by c. $20 \%$ in comparison with the control variant. Maximum dose of polymer did not increase water retention capacity but decreased it by $4 \%$.

Resources of water useful for plants (potentially useful retention PUR), i.e. total amount of easily and hardly available water. Most intensive impact on increasing water amount in soil at $\mathrm{pF}$ in the range 2.2-4.2 was exerted by hydrogel additives of 2 and $4 \mathrm{~g} \cdot \mathrm{dm}^{-3}$ which increased retention capacity by $23 \%$. Smaller $(11 \%)$ increase of sorption capacity was noted at minimum hydrogel dose of $0.5 \mathrm{~g} \cdot \mathrm{dm}^{-3}$. The polymer dose of $6 \mathrm{~g} \cdot \mathrm{dm}^{-3}$ increased PUR by $5 \%$ as compared with the control variant and this was the smallest percent increase of water in soil recorded in all experimental variants.

Water resources at $\mathbf{p F}$ in the range 0-2.2. Comparison of the sorption curves in particular experimental variants shows that hydrogel exerted the strongest effect when applied in the doses of 6 and $4 \mathrm{~g} \cdot \mathrm{dm}^{-3}$ (2.5 and twofold increase of retention capacity, respectively). In the dose of 0.5 and $2 \mathrm{~g} \cdot \mathrm{dm}^{-3}$ it increased retention capacity by 14 and $28 \%$, respectively in comparison with the control variant without hydrogel additives (Fig. 2).

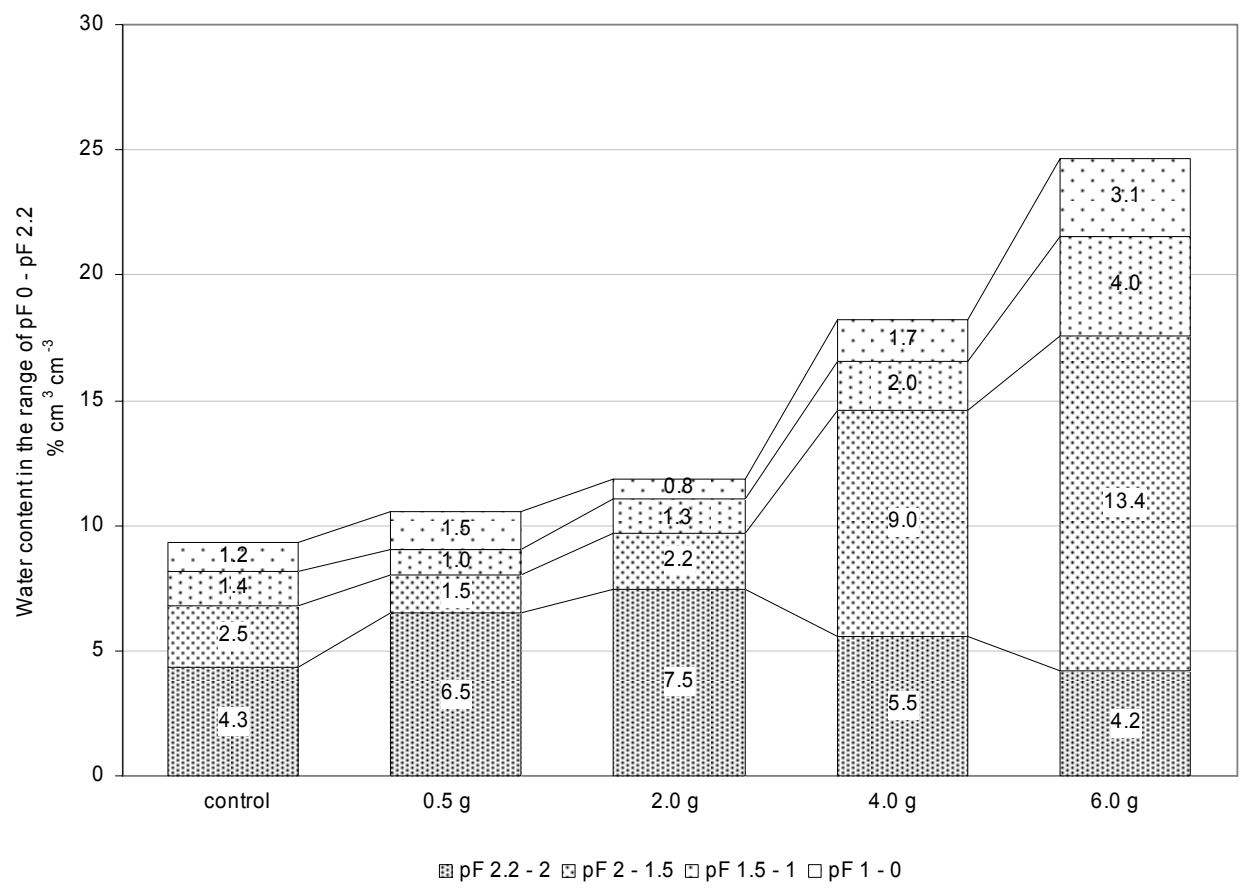

Fig. 2. Water resources in soil at $\mathrm{pF}$ in the range $0-2.2$ for particular hydrogel additives $(0.5,2.0,4.0$ and $6.0 \mathrm{~g}$ per $\mathrm{dm}^{3}$ of soil) and for the control without hydrogel 
Soils enriched in hydrogel in concentrations of 0.5 and $2 \mathrm{~g} \cdot \mathrm{dm}^{-3}$ retained water mainly in the $\mathrm{pF}$ range between 2 and 2.2 producing over 1.5 times higher water retention than in the control. Addition of $4 \mathrm{~g} \cdot \mathrm{dm}^{-3}$ of hydrogel increased retention capacity of the soil by $28 \%$ and addition of $6 \mathrm{~g} \cdot \mathrm{dm}^{-3}-$ decreased it by $2.5 \%$. Within the $\mathrm{pF}$ range of $0-2$ soils enriched with 0.5 and $2 \mathrm{~g} \cdot \mathrm{dm}^{-3}$ of hydrogel were characterised by small water retention properties similar to those of the control. The effect of highest doses of hydrogel on water retention was best visible at $\mathrm{pF}$ in the range of $1.5-2$. It increased retention capacity by $260 \%$ when added in the concentration of $4 \mathrm{~g} \cdot \mathrm{dm}^{-3}$ and by $440 \%$ at the dose of $6 \mathrm{~g} \cdot \mathrm{dm}^{-3}$. At pF between 0 and 1.5 water retention increased by 42 and $170 \%$ at doses of 4 and $6 \mathrm{~g} \cdot \mathrm{dm}^{-3}$, respectively, in comparison with the control.

\section{DISCUSSION}

Results of empirical studies demonstrated positive effect of hydrogel additives on water retention in soil. The strongest impact of hydrogel was noted at water potential $\mathrm{pF}$ between 0 and 2.2. Superabsorber used in the highest doses (4 and 6 $\mathrm{g} \cdot \mathrm{dm}^{-3}$ ) caused 2 or even 2.5 -fold increase of retention capacity. It means that hydrogel mainly retained water which under normal conditions infiltrates down the soil profile. This is of particular importance in soils with washing and soaking type of water supply. In such soils the amount of water in the aeration zone is manly determined by soil retention capacity and by the amount and frequency of atmospheric precipitation (PIERZGALSKI and JEZNACH, 2006). Other authors (HELALIA et al., 1992; AL-DARBY, 1996; PALUSZEK, 2004; 2005; PALUSZEK and ŻEMBROWSKI, 2006a; 2006b; SIVAPALAN, 2006) also indicated that small doses of gel polymers efficiently increased water retention in soils of various grain size structures. Helalia et al. (1992) showed that $2.5-15 \mathrm{~g} \cdot \mathrm{kg}^{-1}$ doses of hydrogels Acryhope and Aquastore-B increased total porosity and the retention of useful water in sandy soils.

Our experiments showed that the effect of hydrogel additives on water resources useful for plants was less pronounced in the $\mathrm{pF}$ range of 2.2-4.2 than in the range of $0-2.2$. The largest $23 \%$ increase of potentially useful retention was observed when hydrogel was applied in doses of 2 and $4 \mathrm{~g} \cdot \mathrm{dm}^{-3}$. The smallest and the largest polymer additives increased the amount of water in soil by 11 and $5 \%$ for 0.5 and $6 \mathrm{~g} \cdot \mathrm{dm}^{-3}$ of hydrogel, respectively.

AL-DARBY (1996) found that the enrichment of sandy soil with 2, 4 and $8 \mathrm{~g} \cdot \mathrm{kg}^{-1}$ doses of hydrogel increased water retention in the range of water potential $\mathrm{pF} 0-4.2$ proportionately to the dose of applied polymer. Water retention at $\mathrm{pF} 3$ increased respectively by 54,130 and $250 \%$ and the retention of useful water by 46, 70 and $91 \%$. According to SIVAPALAN (2006) water capacity increased within the $\mathrm{pF}$ potential of $1-4.2$ when sandy soil was enriched with 0.3 and $0.7 \mathrm{~g} \cdot \mathrm{kg}^{-1}$ of 
gel polyacrylamide. Water capacity of that soil increased, respectively, by 23 and 95\% at $\mathrm{pF}$ 2. PALUSZEK and ŻEMBROWSKI (2006b) described the effect of gel polymer Stockosorb applied in two doses 0.5 and $1 \mathrm{~g} \cdot \mathrm{kg}^{-1}$ on air and water properties of eroded lessive soils. Applied doses improved water-air properties of this soil. Definitely more efficient was the dose of $1 \mathrm{~g} \cdot \mathrm{kg}^{-1}$ which increased actual soil moisture and field water capacity at $\mathrm{pF} 2.2$ as compared with the control variant without polymer. Both doses slightly increased soil moisture (by $0.002-0.005$ $\mathrm{kg} \cdot \mathrm{kg}^{-1}$ ) in the point of strong plant growth inhibition at $\mathrm{pF} 3.2$ and in the point of permanent plant wilting at $\mathrm{pF} 4.2$ (by $0.007-0.009 \mathrm{~kg} \cdot \mathrm{kg}^{-1}$ ). The retention of water useful for plants in the range of $\mathrm{pF} 2.2-4.2$ increased significantly only in objects with the polymer gel additive of $1 \mathrm{~g} \cdot \mathrm{kg}^{-1}$ (by $0.006 \mathrm{~kg} \cdot \mathrm{kg}^{-1}$ on average). The same dose increased the retention of water easily available for plants by $0.011 \mathrm{~kg} \cdot \mathrm{kg}^{-1}$ while the retention of hardly available water ( $\mathrm{pF}$ 3-4.2) slightly decreased (PALUSZEK and ŻEMBROWSKI, 2006b).

Obtained empirical data show ambiguous effects of hydrogel additives on water retention in the point of permanent plant wilting. Only the maximum dose of hydrogel $\left(6 \mathrm{~g} \cdot \mathrm{dm}^{-3}\right)$ increased the amount of water in soil. At smaller polymer doses the decrease of water content in soil was even observed as compared with the control. According to PALUSZEK and ŻEMBROWSKI (2006b) substantial increase of water content in the point of permanent plant wilting in soils enriched with larger hydrogel doses results from strong binding of water with molecular forces by polymer structures. This immobilises part of absorbed water in gel and makes it unavailable for plants (SIVAPALAN, 2006). Performed analyses of water retention in soils, literature data and declarations of the producer of polymer hydrogel Super Absorbent Plus ${ }^{\circledR}$ indicate that almost all water retained by hydrogel is available for plants.

Obtained data confirm that soil enrichment with hydrogel improves retention properties of sandy soil. The largest effect of superabsorbers can be found in porous, dry, poor and highly permeable substrata i.e. such with large contribution of sand, bark, gravel, keramsite (HETMAN et al., 1998). At deep ground water table depths and a lack of contact between the rhizosphere and the zone of capillary irrigation this type of retention is decisive for plant growth in the periods between rainfalls (PODSTAWKA-CHMIELEWSKA et al., 2004; KĘSIK et al. 2006).

\section{CONCLUSIONS}

1. Retention properties of soil enriched with polymer hydrogel differed from typical properties of light soils and resembled those of soils with more compact structure. Application of polymer hydrogels markedly improved retention capacity of sandy soil. 
2. The largest increase of water retention was noted for $\mathrm{pF}$ in the range of 0 -2.2 . It means that sandy soil with hydrogel mainly retains water which under natural conditions would rapidly permeate down the soil profile.

3 . To estimate the effect of hydrogels on retention properties of soils it is necessary to enlarge the scope of studies on the analysis of soil drying dynamics, on the effect of hydrogel on soil structure and water resistance and on the type of soils taking into consideration also more fertile soils.

4. Increased water retention of soil, particularly at higher doses of hydrogel, must not be tantamount with increasing efficiency of sowing and with seedlings' quality. Therefore, further studies are needed to estimate the effect of hydrogel additives on these parameters.

\section{REFERENCES}

1. Al-Darby A.M., 1996. The hydraulic properties of a sandy soil treated with gel-forming soil conditioner. Soil Technol., 9: 15-28.

2. Helalia A.M., El-Amir S., Shawky M.E., 1992. Effect of Acryhope and Aquastore polymers on water regime and porosity in sandy soil. Intern. Agrophys., 6: 19-25.

3. Hetman J., Martyn W., SzOT P., 1998. Możliwość wykorzystania hydrożeli w produkcji ogrodniczej pod osłonami. Zesz. Probl. Post. Nauk Rol., 461: 31-45.

4. KĘSIK T., KONOPIŃSKI M., BLAŻEWICZ-WoŹNIAK M., 2006. Wpływ uprawy przedzimowej mulczu z roślin okrywających na retencję wody, zagęszczenie i porowatość dyferencyjną gleby po przezimowaniu. Acta Agrophys., 7(4): 915-926.

5. PALUSZEK J., 2004. Wpływ hydrożelu Viterra na właściwości gleb erodowanych. Ann. UMCS., Sect. E, 59 (1): 149-156.

6. PALUSZEK J., 2005. Zastosowanie hydrożelu Viterra do ulepszania i ochrony gleb przed erozją wodną. Acta Agrophys., 5 (1): 103-110.

7. PALUSZEK J., ŻEMBROWSKI W., 2006a. Wpływ polimeru żelowego Stockosorb na strukturę agregatową gleb erodowanych. Rocz. AR Pozn., 375, Rol., 65: 115-122.

8. PALUSZEK J., ŻEMBROWSKI W., 2006b. Wpływ polimeru żelowego Stockosorb na właściwości wodne i powietrzne erodowanych gleb płowych. Acta Agrophys., 8 (4): 903-913.

9. Podstawka-ChmielewsKa E., Kurus J., Kosior M., 2004. Wpływ różnych sposobów konserwacji ugoru na zapas wody w glebie lekkiej. Ann. UMCS., Sect. E, 59 (2): 731-736

10. Pierzgalski E., JeznACH J., 2006. Measures for soil water control in Poland. J. Water Land Dev., 10: 79-89.

11. SivaPAlAN S., 2006. Benefits of treating a sandy soil with a crosslinked-type polyacrylamide. Austral. J. Experiment. Agricult., 46: 579-584.

12. WalcZaK R., Ostrowski J., WitkowsKa-WalcZAK B., SŁAwiŃSKi C., 2002. Hydrofizyczne charakterystyki mineralnych gleb ornych Polski. Acta Agrophys. Monogr., 79: 140. 


\section{STRESZCZENIE}

\section{Wpływ dodatku hydrożelu na krzywą retencji wodnej gleby piaszczystej w szkółce leśnej w Julinku}

Słowa kluczowe: gleba piaszczysta, hydrożel polimerowy, retencja wodna gleby, superabsorbent

Szkółki leśne lokalizowane są w najczęściej na siedliskach o glebach lekkich i bardzo lekkich. Gleby te charakteryzują się małymi zdolnościami utrzymywania wody w strefie aeracji, a o jej zasobach decydują głównie opady atmosferyczne. Jednym ze sposobów rozwiązania tych problemów może być zastosowanie hydrożeli polimerowych (superabsorbentów) jako dodatku do gleby.

Celem niniejszej pracy było zbadanie wpływu dodatku hydrożelu polimerowego SuperAbsorbent Plus na krzywą retencji wodnej gleby piaszczystej w szkółce leśnej w Julinku. Do oznaczeń pobrano wierzchnią warstwę gleby do głębokości 15 $\mathrm{cm}$, następnie wymieszano ją i podzielono na 5 części. Każdą część, oprócz próby kontrolnej, wymieszano z założonym dodatkiem hydrożelu w ilości 0,$5 ; 2$; 4; i 6 gramów na $\mathrm{dm}^{3}$ gleby. $Z$ każdej cześci gleby $\mathrm{z}$ założonym dodatkiem hydrożelu oraz próby kontrolnej bez dodatku hydrożelu pobrano po 6 próbek. Pomiary retencji wodnej wykonano za pomocą aparatury firmy Soil Moisture Equipment Corporation (Santa Barbara, California, USA) - LAB 012 w Instytucie Agrofizyki PAN w Lublinie.

Uzyskane wyniki wilgotności w warunkach poszczególnych wartości potencjału wody glebowej przedstawiono w postaci krzywych $\mathrm{pF}$, a analizę właściwości retencyjnych gleby przeprowadzono w poszczególnych zakresach $\mathrm{pF}$ przyjętych za WALCZAK i in. (2002).

Hydrożel dodany do gleby zwiększył jej zdolności retencyjne głównie w zakresie pF mniejszym od 2.0. Największe zwiększenie pojemności wodnej odnotowano w zakresie pF 0-2,2. Oznacza to, że hydrożel zatrzymuje w glebie wodę grawitacyjną, która $\mathrm{w}$ naturalnych warunkach szybko przesiąka $\mathrm{w}$ głąb profilu glebowego, czyniąc ją dostępną dla roślin.

Reviewers:

Dr. Henryk Orzeszyna

Prof. Edward Pierzgalski 